\title{
Pemberdayaan Remaja Sebagai Upaya Pencegahan Penyalahgunaan NAPZA dan Pencegahan HIV/AIDS
}

\author{
Citra Windani Mambang Sari, Mamat Lukman, Desy Indra Yani \\ Fakultas Keperawatan Universitas Padjadjaran \\ Email: citra.windani@unpad.ac.id
}

\begin{abstract}
Abstrak
Tingginya angka kejadian penyalahgunaan NAPZA dan angka HIV/ AIDS pada remaja masih menjadi perhatian dunia untuk terus berupaya mengatasinya. Remaja Babakan Surabaya sebagian besar mempunyai pengetahuan baik tentang NAPZA dan HIV/AIDS tetapi masih ada yang mempunyai pengetahuan kurang baik tentag NAPZA dan HIV/AIDS. Tujuan kegiatan pengabdian masyarakat adalah untuk mengetahui pengaruh pendidikan kesehatan tentang NAPZA dan HIV/ AIDS di Kebon Kangkung dan Babakan Surabaya Kota Bandung. Metode penelitian dengan menggunakan quasi eksperimen dengan 17 remaja dari wilayah kerja Puskesmas Babakan Surabaya. Kuesioner pengetahuan dibuat berdasarkan Kementerian kesehatan. Analisis menggunakan Wilcoxon. Hasil pengabdian ini adalah rata-rata pengetahuan sebelum dilakukan pendidikan kesehatan pada remaja (Median=15, IR=6) dan sesudah diberikan pendidikan kesehatan adalah (Median=19, IR=6). Hasil PKM adalah adanya perbedaan signifikan terhadap pengetahuan remaja tentang NAPZA dan HIV/AIDS di Kelurahan Kebon Kangkung dan Babakan Surabaya Kota Bandung setelah diberikan pendidikan kesehatan $(\mathrm{p}=0.007)$. Saran dari pengabdian ini diharapkan puskesmas dapat melanjutkan dengan memfasilitasi remaja membentuk kegiatan-kegiatan pencegahan NAPZA dan HIV AIDS di kelurahan Babakan Surabaya.
\end{abstract}

Kata kunci: HIV/AIDS, remaja, pemberdayaan, pencegahan.

\begin{abstract}
The high incidence of drug abuse and the rate of HIV / AIDS in adolescents are still the world's attention to continue to work on it. Babakan Surabaya adolescents mostly have good knowledge about drugs and HIV / AIDS but there are still those who have poor knowledge about drugs and HIV / AIDS. The purpose of community service activities was to analyze the effect of health education about drugs and HIV / AIDS in Kebon Kangkung and Babakan Surabaya City of Bandung. The research method used quasi experiments with 17 teenagers from the Babakan Health Center Surabaya work area. The knowledge questionnaire was made based on the Ministry of Health. Data were analyzed using Wilcoxon. The results of this service found that the median knowledge before health education conducted in adolescents was 15 $(\mathrm{IR}=6)$ and median after being given health education was 19 (interval range $=6$ ). The community service results found that there were significant differences in adolescent knowledge about drugs and HIV / AIDS in Kebon Kangkung and Babakan Surabaya, Bandung, after being given health education $(\mathrm{p}=$ 0.007). Suggestions from this service are that the community health centers are expected to continue by facilitating youth to form prevention activities for drugs and HIV AIDS in Babakan Surabaya.
\end{abstract}

Keywords: Adolescent, empowerment, HIV/AIDS, prevention. 


\section{Pendahuluan}

Tingginya angka kejadian penyalahgunaan NAPZA dan angka HIV/ AIDS masih menjadi perhatian dunia untuk terus berupaya mengatasinya. Pasca periode Millenium Development Goal's, permasalahan ini masih dinyatakan sebagai bagian penting dalam agenda-agenda kesepakatan antar dunia berikutnya (UNAIDS, 2015). Tingginya angka ini banyak terdapat pada remaja.

Remaja karang taruna biasanya adalah remaja yang memiliki kepedulian lebih terhadap lingkungannya dan memilki rasa kebersamaan yang dalam diantara mereka. Di Kelurahan Kebon Kangkung, pengetahuan remaja tentang penyalahgunaan NAPZA masih kurang. Remaja di Kelurahan ini juga belum ada pembinaan khusus terhadap mereka. Kegiatan mereka masih terbatas pada kumpul-kumpul diwaktu senggang dan sesekali terlibat dalam kerja bakti kebersihan lingkungan. Belum ada kegiatan dalam bidang kesehatan yang positif dan terarah yang mereka lakukan. Bahkan remaja yang tergabung dalam karang taruna juga memiliki perilaku tidak sehat seperti merokok dan sebagian kecil mereka memiliki tato dan tindik. Diantara mereka ada yang masih bersekolah tapi juga ada yang sudah putus sekolah dari SMP. Bagi yang sudah tidak bersekolah mereka menghabiskan waktu dengan bekerja atau menganggur di rumah. Oleh sebab itu, maka dipandang perlu untuk dilakukan kegiatan pengabdian masyarakat ini untuk menyelesaikan sebagian permasalahan remaja di Kelurahan Kebon Kangkung, khususnya terkait penyalahgunaan NAPZA dan HIV/ AIDS. Yang merupakan permasalahan pada remaja karang taruna di Kelurahan Kebon Kangkung dan Babakan Surabaya adalah 1. Belum pernah mendapatkan pelatihan khusus tentang penyalahgunaan NAPZA. Berdasarkan kajian situasi melalui diskusi kelompok terfokus terhadap masing-masing remaja karang taruna dari kelurahan Kebon Kangkung diketahui bahwa pengetahuan remaja kurang baik sekitar 190 (52.3\%) dan tentang HIV/AIDS sekitar 241 orang $(66.39 \%)$. 2. Lingkungan yang tinggi angka kejadian HIV/ AIDS nya dan geografis yang di perkotaan, namun mereka belum memiliki akses dan jejaring dengan berbagai institusi dan LSM yang bergerak di bidang NAPZA dan HIV/ AIDS di Kota Bandung. Padahal, jika akses institusi dan LSM terbuka secara langsung dan lebih luas ke masyarakat maka upaya pengendalian bisa lebih optimal lagi. Tujuan 
kegiatan ini adalah untuk mengetahui pengaruh pendidikan kesehatan tentang NAPZA dan HIV/ AIDS di Kebon Kangkung dan Babakan Surabaya Kota Bandung.

\section{Metode}

Metode penelitian dengan menggunakan quasi eksperimen dengan 17 remaja sebagai responden dari wilayah kerja Puskesmas Babakan Surabaya. Metode pengabdian ini terdiri dari tiga tahap. 1). Fase pertama. Pada fase ini, tim pengabdian berkoordinasi dengan mitra dan juga pihak RW serta kelurahan untuk menyepakati kembali tujuan keseluruhan dari kegiatan. Tim pengabdian bersama mitra dari masing-masing kelurahan menentukan 10 orang remaja karang taruna untuk diikutkan pada "Penyalahgunaan NAPZA dan Pelatihan Khusus HIV/ AIDS bagi Remaja (Training of Trainer)”. Sepuluh orang remaja dari masing-masing kelurahan inilah kemudian yang akan menjadi Duta HIV/ AIDS Kelurahan. Kemudian pengusul PKM bersama mitra mempersiapkan pelatihan penerapan modul penyalahgunaan NPAZA dann pengendalian HIV/ AIDS pada remaja yang telah disusun terlebih dahulu oleh pengusul PKM. 2). Tahap kedua. Pelatihan langsung pada mitra tentang "Penyalahgunaan NAPZA dan pengendalian HIV/ AIDS pada remaja”. Pelatihan ini bertujuan untuk meningkatkan pengetahuan, sikap, motivasi, kesiapan, dan keterampilan mitra dalam Penyalahgunaan NAPZA dan pengendalian HIV/ AIDS pada remaja di wilayahnya. Peran mitra pada kegiatan ini adalah aktif sebagai peserta pelatihan. Luaran dari pelatihan ini adalah modul dan metode pelatihan yang tepat untuk pemberdayaan karang taruna dalam Penyalahgunaan NAPZA dan pengendalian HIV/ AIDS. Adapun kriteria hasilnya adalah setidaknya sepuluh orang remaja dari masing-masing karang taruna mengikuti pelatihan dan setidaknya $80 \%$ peserta pelatihan (mitra) memiliki pengetahuan, sikap, motivasi, kesiapan, dan keterampilan yang baik dalam Penyalahgunaan NAPZA dan pengendalian HIV/ AIDS pada remaja. 3. Tahap Evaluasi. Secara keseluruhan, evaluasi dilakukan terhadap input, proses, dan output kegiatan.

Kuesioner pengetahuan dibuat berdasarkan Kementerian kesehatan. Analisis menggunakan Wilcoxon. 


\section{Hasil}

Kegiatan pengabdian ini dibagi menjadi 3 tahap yaitu brainstorming, pelatihan remaja. Metode pelaksanaan PKM ini terdiri dari tiga tahap yaitu pertemuan dengan tokoh masyarakat dan remaja, serta pelatihan remaja di Kelurahan Kebon Kangkung dan Babakan Surabaya Kota Bandung. Tahap awal dari PKM ini adalah pertemuan dengan remaja dan tokoh masyarakat dan pelatihan remaja di Kelurahan Kebon Jayanti dan Babakan Surabaya Kota Bandung. Jumlah remaja yang diundang pelatihan adalah perwakilan remaja dari masing-masing RW, materi pelatihan berupa Konsep Kesehatan Reproduksi pada remaja, NAPZA dan HIV/AIDS.

Tabel 1 Karakteristik Responden Kelurahan Babakan Surabaya Kota Bandung

\begin{tabular}{lrr}
\hline \multicolumn{1}{c}{ Variabel } & Frekuensi & Persentase \\
\hline Usia & 6 & \\
$12-15$ & 11 & 29.4 \\
$16-19$ & & \\
\hline Jenis Kelamin & 4 & 23.5 \\
Laki-laki & 13 & 76.5 \\
Perempuan & \multicolumn{2}{c}{} \\
\hline Tingkat Pendidikan & 5 & 29.4 \\
SMP & 10 & 58.8 \\
SMA & 2 & 11.8 \\
Kuliah & \multicolumn{2}{c}{} \\
\hline
\end{tabular}

Tabel 2 Uji Beda Rata-rata Pengetahuan Remaja Sebelum dan Sesudah Pelatihan

\begin{tabular}{ccccc}
\hline Variabel & \multicolumn{2}{c}{ Median (IR) } & Z & p-value \\
\cline { 2 - 3 } & Sebelum & Sesudah & & \\
\hline Pengetahuan & $15(6)$ & $19(6)$ & & \\
\hline
\end{tabular}

Dari Tabel 2 diatas, dapat diketahui bahwa ada perbedaan signifikan sebelum dan sesudah pelatihan pada pengetahuan remaja ( $p$-value=0.007). Hal ini dikarenakan 
remaja dapat memahami materi yang diberikan dank arena metode yang dilakukan divariasikan selain ceramah tanya jawab.

\section{Pembahasan}

Penelitian ini merupakan aplikasi penerapan model pendidikan kesehatan dalam program edukasi berbasis Komunitas. Peran perawat komunitas yang memiliki peran sebagai instruktur pendidikan kesehatan dalam memberikan pendidikan kesehatan mengenai pengetahuan NAPZA dan pencegahan HIV/AIDS. Pelatihan remaja tentang penyalahgunaan NAPZA dan pencegahan HIV/AIDS di Kelurahan Kebon Kangkung dan Babakan Surabaya Kota Bandung dilaksanakan sesuai dengan perencanaan dengan remaja dan mendapat dukungan dari LPPM kelurahan. Hal ini dapat terlaksana, dari upaya tim PKM dan juga dukungan pihak Kelurahan serta kerja sama remaja di RW.

\section{Simpulan}

Adanya perbedaan signifikan terhadap pengetahuan remaja tentang NAPZA dan HIV/AIDS di Kelurahan Kebon Kangkung dan Babakan Surabaya Kota Bandung setelah diberikan pendidikan kesehatan ( $\mathrm{p}=0.007)$. Saran dari pengabdian ini diharapkan puskesmas dapat melanjutkan dengan memfasilitasi remaja membentuk kegiatankegiatan pencegahan NAPZA dan HIV AIDS di kelurahan Babakan Surabaya.

\section{Daftar Pustaka}

Dinas Kesehatan Kota Bandung. 2015. Profil Kesehatan Kota Bandung. Diakses melalui http://www.bandung.go.id/index.php?fa=dilemtek.detail\&id=8.

Pusat Data dan Informasi Kementerian Kesehatan RI. 2015. Situasi dan Analisis HIV/ AIDS di Indonesia. Jakarta: Kemenkes RI.

Fujiyanti, I., Sari, PS, Sari, CWM. 2013. Pengaruh Program Pendidikan Kesehatan Berbasis Sekolah Tentang Kekerasan Dalam Pacaran Terhadap Pengetahuan, Sikap, Dan Perilaku Siswi Sma Negeri Di Kota Bandung. Bandung: fakultas Keperawatan Unpad.

Riset Kesehatan Dasar (Riskesdas). 2013. Jakarta : Kementerian Kesehatan RI. 
Citra Windani: Pemberdayaan Remaja Sebagai Upaya Pencegahan Penyalahgunaan NAPZA

UNAIDS. 2015. AIDS Info. Diakses melalui http:// www.unaids.org/en/dataanalysis. 